\title{
ЗМІНИ В СИСТЕМІ ПЕРОКСИДНОГО ОКИСНЕННЯ ЛІПІДІВ У ПІДДОСЛІДНИХ ТВАРИН ВНАСЛІДОК МОДЕЛЬОВАНОЇ ПОЄДНАНОЇ АБДОМІНО-СКЕЛЕТНОЇ ТРАВМИ ТА ІШЕМІЇ-РЕПЕРФУЗІЇ НИЖНІХ КІНЦІВОК
}

\begin{abstract}
Вступ. У статті наведено результати експериментального дослідження, під час якого вивчали вплив реперфузії нижніх кінцівок, після накладання кровоспинних джгутів, на зміни показників системи пероксидного окиснення ліпідів у сироватці крові за умов абдоміно-скелетної травми і масивної зовнішньої крововтрати. Вони показали, що реперфузія нижніх кінцівок у поєднанні з модельованими травмами викликає значну активацію цієї системи протягом 21-го дня посттравматичного періоду.

Мета дослідження - вивчити вплив реперфузії кінцівки на моделі поєднаної абдоміно-скелетної травми на зміни показників системи пероксидного окиснення ліпідів.

Методи дослідження. Експеримент проведено на 130-ти нелінійних щурах-самцях масою 190-220 ट. У дослідних групах було змодельовано реперфузію нижніх кінцівок у поєднанні з абдоміно-скелетною травмою та проаналізовано динаміку змін показників ТБК-активних продуктів і дієнових кон'югатів до 21-ї доби посттравматичного періоду. Достовірність відмінностей між контрольною та дослідними групами оцінювали з використанням непараметричного критерію Манна - Уітні.

Результати й обговорення. Результати аналізу динаміки змін показників дієнових кон'югатів і ТБКактивних продуктів пероксидного окиснення ліпідів у дослідних групах свідчать про те, що накладання кровоспинних джгутів на обидві нижні кінцівки піддослідних тварин викликало значну активацію системи пероксидного окиснення ліпідів у посттравматичний період. За своєю динамікою активація цієї системи у групі піддослідних тварин із скелетною травмою, яким накладали кровоспинні джгути, та групі піддослідних тварин, в яких скелетна травма поєднувалась із закритою травмою органів черевної порожнини, була подібною. Таким чином, ішемію-реперфузію нижніх кінцівок можна розглядати як компонент поєднаної травми.

Висновок. Накладання кровоспинних джгутів на дві нижні кінцівки на 2 год викликає тривалу активацію системи ліпідної пероксидації, що підтверджується статистично достовірним $(p<0,05)$ збільшенням рівня дієнових кон'югатів і ТБК-активних продуктів пероксидного окиснення ліпідів з максимумом через 21 добу в постттавматичний період.
\end{abstract}

КЛЮЧОВІ СЛОВА: ішемія-реперфузія; джгут; експеримент; поєднана травма; дієнові кон'югати; ТБК-активні продукти; кровотеча.

ВСТУП. Поєднана травма залишається основною причиною летальних наслідків і травматизму серед осіб працездатного віку. Прогнозується, що кількість травмованих осіб буде зростати протягом наступних 20-ти років [1]. Відомо, що лікування травмованих $€$ викликом для фрахівців, а результати лікування залежать від спадкоємності дій догоспітального і госпітального етапів [2, 3].

Особливу категорію становить поєднана травма, ускладнена масивною крововтратою. Оскільки крововтрата 3 кінцівок $є$ основною превентивною травмою в постраждалих на (с) С. В. Гаріян, 2020. догоспітальному етапі, останнім часом значно частіше почали використовувати кровоспинні джгути $[4,5]$. Вони мають очевидні переваги. Але, поряд із цим, існують експериментальні роботи, в яких доведено, що кровоспинні джгути здатні викликати розвиток системних змін. Індукована накладанням джгута ішемія кінцівки призводить до реперфузійних травм не тільки скелетних м'язів, але іжиттєво важливих органів, зокрема мозку, серця, легень та нирок. Відновлення кровотоку після періоду ішемії має важливе значення для запобігання незворотній смерті клітин, однак реперсузія може посилити вторинні ушкодження після ішемії $[6,7]$. 
Важливим процесом при цьому є активація ліпідної пероксидації, яка належить до універсальних механізмів ушкодження [8]. В ії патогенезі важливу роль відіграє гіпоксія, що розвивається на фооні гіповолемії. У кінцевому результаті порушуються процеси мікроциркуляції - як локально, так і в органах та тканинах, віддалених від місця травми [9]. Відомо, що за цих умов накопичуються активні фрорми кисню, які за рахунок пероксидного окиснення ліпідів клітинних мембран зумовлюють їх деструкцію, дистрофрію і некроз клітин, накопичення ендотоксинів.

Вплив ішемії-реперфузії на життєво важливі органи добре вивчено, уточнення потребують тільки окремі патофрізіолочні ланки. Однак фрактично не досліджено впливу ішемії-реперфузії внаслідок накладання кровоспинного джгута при поєднаній травмі [10] та фрункції кісткової тканини і тканин великих суглобів. Це і стало метою даного експериментального дослідження.

Метадослідження-вивчити вплив реперфузії кінцівки на моделі поєднаної абдоміно-скелетної травми на зміни показників системи пероксидного окиснення ліпідів.

МЕТОДИ ДОСЛІДЖЕННЯ. РОбочою гіпотезою експериментального дослідження є припущення, що використання кровоспинного джгута і подальша реперфузія ішемізованих тканин призводять до значних системних змін з порушенням життєдіяльності внутрішніх органів при поєднаній абдоміно-скелетній травмі на фроні гіповолемічного шоку та можуть спричиняти зміни, що впливають на функцію кісткової тканини.

3 метою реалізації поставленої мети на 130-ти нелінійних щурах-самцях масою 190 220 г було виконано експериментальне дослідження. Усіх їх поділили на чотири групи: контрольна (КГ) - інтактні тварини (10 щурів); 1-ша дослідна (ГД-1) - тварини, яким моделювали перелом стегна, масивну зовнішню крововтрату й ішемію-реперфузію нижніх кінцівок (40 щурів); 2-га дослідна (ГД-2) - тварини, яким моделювали скелетну травму, масивну зовнішню крововтрату і закриту травму органів черевної порожнини (40 щурів); 3-тя дослідна (ГД-3) - тварини, яким моделювали закриту травму органів черевної порожнини, скелетну травму, масивну зовнішню крововтрату й ішемію-реперсузію нижніх кінцівок (40 щурів).

Усі експерименти з нанесення травм виконували за умов тіопентал-натрієвого знеболювання (40 мг·кг-1 маси). Закритий перелом стегнової кістки моделювали шляхом нанесення однократного дозованого удару спеціально розроб- леним пристроєм по стегну, який викликав закритий перелом (площина ударного пристрою становила 0,5 см², сила удару - понад 120 кг $\left./ \mathrm{cm}^{2}\right)$. Закриту травму органів черевної порожнини моделювали шляхом нанесення двох дозованих ударів у ділянку черевної порожнини спеціально розробленим пристроєм. Завдяки дозованому удару в ділянку черевної порожнини моделювали закриту травму органів черевної порожнини. Силу удару пристрою розраховували таким чином, щоб викликати закриту травму органів черевної порожнини без масивної крововтрати площина ударного пристрою становила 2,5 см², сила удару не перевищувала 60 кг/см². За таких параметрів виникали внутрішньоорганні гематоми 3 ушкодженням паренхіми і дрібних внутрішньоорганних кровоносних судин, а також забої та невеликі радіальні розриви паренхіматозних органів.

Масивну зовнішню крововтрату моделювали шляхом виконання достатнього операційного доступу до стегнових судин на протилежному від перелому стегнової кістки боці, далі під судинний пучок заводили лігатуру та розсікали судини. Після цього здійснювали забір 20-22 \% циркулюючої крові протягом 1 хв (гостра крововтрата). Кров забирали шляхом просочування та зважування ватного спонжика. Одразу після відбору достатньої кількості крові кровотечу зупиняли шляхом зав'язування лігатур.

Використовували модифікацію широкого еластичного кровоспинного джгута торговельної марки "SWAT ${ }^{\circledR}$ виробництва CША. Попередньо перед накладанням 3 оригінального полотна кровоспинного джгута вирізали шматок шириною 1,5 см та довжиною 10 см. Достатнє розтягнення джгута, для повного перетискання судин нижніх кінцівок тварин, контролювали за допомогою спеціальних індикаторів, які виробник наніс на його поверхню.

Тварин виводили з експерименту через 3, 7, 14 та 21 доби після моделювання травм. Під тіопентал-натрієвим знеболюванням здійснювали забій усіх щурів відповідної групи методом тотального кровопускання із серця.

У сироватці крові тварин визначали рівень дієнових кон'югатів (ДК) і ТБК-активних продуктів пероксидного окиснення ліпідів (ПОЛ) [11]. Досліджували їх у Центральній науковій лабораторії Тернопільського державного медичного університету імені І. Я. Горбачевського.

Достовірність відмінностей між контрольною і дослідними групами оцінювали 3 використанням непараметричного критерію Манна - Уїтні. Відмінності вважали істинними при вірогідності нульової гіпотези менше 5 \% $(p<0,05)$. 
РЕЗУЛЬТАТИ Й ОБГОВОРЕННЯ. АНаЛіЗ динаміки змін рівня ДК у дослідних групах показав (табл. 1), що у ГД-1 він достовірно $(p<0,05)$ перевищував контрольні показники: через 3 доби - на 75,6 \%, через 7 діб - на $157,6 \%$, через 14 діб - на 119,9\%, через 21 добу - на 101,6 \%. У ГД-2 через 3 доби зріс на 100,3\% ( $<<0,05)$, через 7 діб - на 170,9\% $(p<0,05)$, через 14 діб - на 153,5\% ( $p<0,05)$, через 21 добу посттравматичного періоду - на 136,1 \% $(\mathrm{p}<0,05)$. У ГД-3 під час усього спостереження рівень ДК був достовірно більшим $(p<0,05)$ від контрольних показників: через 3 доби - на 224,1 \%, через 7 діб - на 290,2 \%, через 14 діб на 312,7 \%, через 21 добу - на 394,3 \%, що було їх максимальним значенням.

При порівнюванні показника ДК у дослідних групах за термінами спостереження встановлено, що в ГД-1 через 3 доби він виявився меншим порівняно з ГД-2 та ГД-3, відповідно, на 15,8 $\left(p_{1-2}<0,05\right)$ і $102,1 \%\left(p_{1-3}<0,001\right)$. У ГД-3 був статистично більшим, ніж у ГД-2, на $74,5 \%$ $\left(p_{2-3}<0,001\right)$. Через 7 діб спостерігали аналогічну тенденцію: у ГД-3 рівень ДК достовірно перевищував ГД-1 та ГД-2, відповідно, на 55,7 \% $\left(p_{1-3}<0,001\right)$ і $48,9 \%\left(p_{2-3}<0,001\right)$. У ГД-1 він був меншим, ніж у ГД-2, на 4,5\%, що виявилось статистично не достовірним ( $\left.p_{1-2}>0,05\right)$. Через 14 діб посттравматичного періоду в ГД-1 та ГД-2 відзначали зниження показника ДК, у ГД-3 - його зростання. Так, у ГД-3 він був статистично більшим, ніж у ГД-1 та ГД-2, відповідно, на 87,6 \% $\mathrm{p}_{1-3}<0,001$ i $62,8 \%\left(\mathrm{p}_{2-3}<0,001\right)$. У ГД-1 рівень ДК був меншим, ніж у ГД-2, на $15,3 \%\left(p_{1-2}>0,05\right)$, що виявилось статистично не достовірним. Через 21 добу посттравматичного періоду він зростав у ГД-3 порівняно з попереднім показником, тоді як у ГД-1 та ГД-2 - знижувався. Так, у ГД-3 рівень
ДК був більшим, ніж у ГД-1 та ГД-2, відповідно, на $145,2 \%\left(p_{1-3}<0,001\right)$ і $109,4 \%\left(p_{2-3}<0,01\right)$. У ГД-2 він перевищував такий у ГД-1 на 17,1 \% $\left(p_{1-2}>0,05\right)$.

При аналізі динаміки змін рівня ДКу дослідних групах встановлено, що у ГД-1 він досягав максимального значення через 7 діб, коли перевищував показник через 3 доби на 41,8 \% $(p<0,05)$, до 14-ї доби знизився на 10,0\% ( $p>0,05)$, до 21-ї доби - на 8,3 \% відносно попередніх ( $p>0,05)$. Аналогічну тенденцію спостерігали й у ГД-2, де рівень ДК через 7 діб зріс на $35,2 \%(p<0,05)$ відносно показника через 3 доби. До 14-ї доби він зменшився щодо показника через 7 діб на 6,4% ( $>>0,05)$, до 21-ї доби знизився відносно показника через 14 діб на $6,8 \%$, що було статистично не достовірним ( $p>0,05)$. У ГД-3 рівень ДК односпрямовано підвищувався до кінця спостереження. Через 7 діб він збільшився щодо показника через 3 доби на 20,4 \% ( $p<0,05)$, через 14 діб - на 5,8 \% (p>0,05), до 21-ї доби - на 19,8 \% (p<0,05).

Зважаючи на вищеописані результати дослідження, можна зробити висновок, що зміни показників ТБК-активних продуктів ПОЛ і ДК за своєю динамікою були дуже подібними (табл. 2).

Так, аналіз динаміки змін рівня ТБК-активних продуктів ПОЛ у дослідних групах показав, що у ГД-1 через 3 доби він достовірно $(p<0,05)$ перевищував контрольні показники на 82,4\%, через 7 діб - на 101,6 \%, через 14 діб - на 71,2 \%, через 21 добу - на 64,9%. У ГД-2 через 3 доби збільшився на 91,2 \% $(p<0,05)$, через 7 діб - на $153,2 \%(p<0,05)$, через 14 діб - на 148,4 \% $(p<0,05)$, через 21 добу посттравматичного періоду - на 108,9 \% $(p<0,05)$. У ГД-3 протягом цього спостереження рівень ТБК-активних продуктів ПОЛ був достовірно вищим $(p<0,05)$ від

Таблиця 1 - Рівень дієнових кон'югатів у крові (ум. од. $\left.\mathrm{r}^{-1}\right)$ у динаміці поєднаної травми в групах дослідження (Me (LQ; UQ)) - медіана (верхній і нижній квартилі)

\begin{tabular}{|c|c|c|c|c|c|}
\hline \multirow{2}{*}{$\begin{array}{c}\text { Група } \\
\text { дослідження }\end{array}$} & \multirow{2}{*}{ КГ } & \multicolumn{4}{|c|}{ Термін дослідження, доба } \\
\hline & & 3-тя & 7-ма & 14-та & 21-ша \\
\hline ГД-1 & \multirow[t]{3}{*}{$\begin{array}{c}3,16 \\
(2,53 ; 3,71) \\
(n=10)\end{array}$} & $\begin{array}{c}5,74^{*} \\
(5,05 ; 6,16) \\
(n=9)\end{array}$ & $\begin{array}{c}8,14^{*} \\
(7,56 ; 8,93) \\
(n=9)\end{array}$ & $\begin{array}{c}6,95^{\star} \\
(6,38 ; 8,32) \\
(n=8)\end{array}$ & $\begin{array}{c}6,37^{*} \\
(6,09 ; 7,30) \\
(n=9)\end{array}$ \\
\hline ГД-2 & & $\begin{array}{c}6,33^{*} \\
(5,90 ; 6,75) \\
(n=8)\end{array}$ & $\begin{array}{c}8,56^{\star} \\
(7,10 ; 9,97) \\
(n=8)\end{array}$ & $\begin{array}{c}8,01^{*} \\
(6,29 ; 10,29) \\
(n=8)\end{array}$ & $\begin{array}{c}7,46^{\star} \\
(6,41 ; 8,42) \\
(n=8)\end{array}$ \\
\hline ГД-3 & & $\begin{array}{c}10,24^{*} \\
(9,92 ; 13,00) \\
(n=7)\end{array}$ & $\begin{array}{c}12,33^{\star} \\
(11,54 ; 14,01) \\
(n=6)\end{array}$ & $\begin{array}{c}13,04^{\star} \\
(12,27 ; 14,05) \\
(n=6)\end{array}$ & $\begin{array}{c}15,62^{*} \\
(15,35 ; 17,01) \\
(n=6)\end{array}$ \\
\hline \multicolumn{2}{|c|}{$\frac{1}{p_{1-2}}$} & $<0,05$ & $>0,05$ & $>0,05$ & $>0,05$ \\
\hline \multicolumn{2}{|c|}{$\mathrm{p}_{1-3}$} & $<0,001$ & $<0,001$ & $<0,001$ & $<0,001$ \\
\hline \multicolumn{2}{|c|}{$p_{2-3}$} & $<0,001$ & $<0,001$ & $<0,001$ & $<0,001$ \\
\hline
\end{tabular}

Примітки. Тут і в таблиці 2:

1. * - відмінності стосовно КГ статистично достовірні $(p<0,05)$.

2. $\mathrm{p}_{1-2}$ - достовірність відмінностей показника між ГД-1 та ГД-2; $\mathrm{p}_{1-3}$ - між ГД-1 і ГД-3; $\mathrm{p}_{2-3}-$ між ГД-2 та ГД-3. 
Таблиця 2 - Рівень ТБК-активних продуктів пероксидного окиснення ліпідів у крові (мкмоль/кг у динаміці реперфузії (Me (LQ; UQ) - медіана (нижній і верхній квартилі))

\begin{tabular}{|c|c|c|c|c|c|}
\hline \multirow{2}{*}{$\begin{array}{c}\text { Група } \\
\text { дослідження }\end{array}$} & \multirow{2}{*}{ КГ } & \multicolumn{4}{|c|}{ Термін дослідження, доба } \\
\hline & & 3-тя & 7-ма & 14-та & 21-ша \\
\hline ГД-1 & \multirow[t]{3}{*}{$\begin{array}{c}5,56 \\
(5,26 ; 6,91) \\
(n=10)\end{array}$} & $\begin{array}{c}10,14^{\star} \\
(9,79 ; 10,36) \\
(n=9)\end{array}$ & $\begin{array}{c}11,21^{*} \\
(9,82 ; 13,66) \\
(n=9)\end{array}$ & $\begin{array}{c}9,52^{*} \\
(9,12 ; 10,23) \\
(n=8)\end{array}$ & $\begin{array}{c}9,17^{*} \\
(8,39 ; 9,66) \\
(n=9)\end{array}$ \\
\hline ГД-2 & & $\begin{array}{c}10,63^{\star} \\
(10,13 ; 12,52) \\
(n=8)\end{array}$ & $\begin{array}{c}14,08^{\star} \\
(12,75 ; 14,52) \\
(n=8)\end{array}$ & $\begin{array}{c}13,81^{\star} \\
(11,92 ; 14,47) \\
(n=8)\end{array}$ & $\begin{array}{c}11,49^{\star} \\
(10,10 ; 12,59) \\
(n=8)\end{array}$ \\
\hline ГД-3 & & $\begin{array}{c}15,87^{*} \\
(14,11 ; 16,79) \\
(n=7)\end{array}$ & $\begin{array}{c}16,92^{*} \\
(15,13 ; 18,73) \\
(n=6)\end{array}$ & $\begin{array}{c}17,37^{*} \\
(16,83 ; 18,18) \\
(n=6)\end{array}$ & $\begin{array}{c}20,84^{*} \\
(20,08 ; 21,47) \\
(n=6)\end{array}$ \\
\hline \multicolumn{2}{|c|}{$p_{1-2}$} & $>0,05$ & $<0,05$ & $<0,001$ & $<0,001$ \\
\hline \multicolumn{2}{|c|}{$p_{1-3}$} & $<0,001$ & $<0,001$ & $<0,001$ & $<0,001$ \\
\hline \multicolumn{2}{|c|}{$p_{2-3}$} & $<0,001$ & $<0,01$ & $<0,001$ & $<0,001$ \\
\hline
\end{tabular}

контрольних показників: через 3 доби - на 185,4 \%, через 7 діб - на 204,3 \%, через 14 діб на 212,4 \%, через 21 добу - на 274,8 \%, що було їх максимальним значенням.

При порівнюванні показника ТБК-активних продуктів ПОЛ у дослідних групах за термінами спостереження встановлено, що в ГД-1 через 3 доби він виявився меншим порівняно з ГД-2 та ГД-3, відповідно, на 4,8 \% ( $\left.p_{1-2}>0,05\right)$ і 56,5\% $\left(\mathrm{p}_{1-3}<0,001\right)$. УГД-3 був статистично більшим, ніж у ГД-2, на 49,3\% ( $\left.p_{2-3}<0,001\right)$. Через 7 діб спостерігали аналогічну тенденцію: у ГД-3 рівень ТБК-активних продуктів ПОЛ достовірно перевищував показники ГД-1 та ГД-2, відповідно, на 50,9\% ( $\left.p_{1-3}<0,001\right)$ і 20,2\% $\left(p_{2-3}<0,01\right)$. У ГД-1 він був меншим, ніж у ГД-2, на 25,6\% $\left(p_{1-2}<0,05\right)$. Через 14 діб посттравматичного періоду в ГД-1 та ГД-2 відзначали зниження показника ТБКактивних продуктів ПОЛ, у ГД-3 - його зростання. Так, у ГД-3 він був статистично більшим, ніж у ГД-1 та ГД-2, відповідно, на 82,5\% $\left(\mathrm{p}_{1-3}<0,001\right) \mathrm{i}$ $25,8 \%\left(p_{2-3}<0,001\right)$. У ГД-1 рівень ТБК-активних продуктів ПОЛ був меншим, ніжу ГД-2, на 45,1 \% $\left(p_{1-2}<0,001\right)$. Через 21 добу посттравматичного періоду він зростав у ГД-3 порівняно з попереднім показником, тоді як у ГД-1 та ГД-2 - знижувався. Так, у ГД-3 рівень ТБК-активних продуктів ПОЛ був більшим, ніж у ГД-1 та ГД-2, на 127,3 \% $\left(p_{1-3}<0,001\right)$ і $81,4 \%\left(p_{2-3}<0,01\right)$. У ГД-2 він перевищував показник у ГД-1 на 25,3 \% $\left(p_{1-2}<0,001\right)$.

При аналізі динаміки змін рівня ТБК-активних продуктів ПОЛ у дослідних групах встановлено, що у ГД-1 він досягав максимального значення через 7 діб, коли перевищував показник через 3 доби на 10,6 \% (p>0,05), до 14-ї доби знизився на 15,1 \% (р>0,05), до 21-ї доби - на 3,7 \% відносно попередніх ( $p>0,05)$. Аналогічну тенденцію спостерігали й у ГД-2, де рівень ТБК-активних продуктів ПОЛ через 7 діб зріс на 32,5 \% $(p<0,05)$ відносно показника через 3 доби. До 14-ї доби він зменшився щодо показника через
7 діб на 1,9 \% (р>0,05), до 21-ї доби знизився відносно показника через 14 діб на 16,8 \% ( $<<0,05)$. У ГД-3 рівень ТБК-активних продуктів ПОЛ односпрямовано підвищувався до кінця спостереження. Через 7 діб він збільшився щодо показника через 3 доби на 6,6 \% ( $>0,05)$, через 14 діб-на 2,7 \% (p>0,05), до 21-ї доби-на 19,9 \% $(p<0,05)$.

Таким чином, провівшианалізвищенаведених показників, можна зробити висновок, що модельовані травми викликають тривалу активацію системи ПОЛ у сироватці крові піддослідних тварин. Про це свідчить відсутність нормалізації показників ДК і ТБК-активних продуктів ПОЛ через 21 добу посттравматичного періоду.

Слід зазначити, що за своєю динамікою активація системи пОЛ у групі піддослідних тварин із скелетною травмою, яким накладали кровоспинні джгути, та групі піддослідних тварин, в яких скелетна травма поєднувалась із закритою травмою органів черевної порожнини, була подібною. Таким чином, ішемію-реперфузію нижніх кінцівок можна розглядати як компонент поєднаної травми. Також можна зробити припущення, що у відповідь на реперфузію відсутні стійкі адаптаційні механізми, однакце твердження потребує додаткового вивчення.

Можна зробити висновок, що ішемія-реперфрузія нижніх кінцівок значно потенціює та посилює розвиток системних змін в організмі при її поєднанні з травмою органів черевної порожнини, скелетною травмою і кровотечею. В основі цього твердження лежать зміни індикаторних показників системи ПОЛ у ГД-3, в якій показники ДК і ТБК-активних продуктів ПОЛ значно перевищували такі в інших дослідних групах.

ВИСНОВКИ. 1. Рівень дієнових кон'югатів у всіх групах піддослідних тварин значно зростав у всіх контрольних точках спостереження. Найбільшу динаміку змін спостерігали у групі 
піддослідних тварин, в яких моделювали закриту травму органів черевної порожнини, скелетну травму, масивну зовнішню крововтрату та ішемію-репердузію нижніх кінцівок. Так, рівень дієнових кон'югатів у них постійно підвищувався та досягав максимальних показників до 21-ї доби і був більшим від контрольних у 3,9 раза $(p<0,05)$. Аналогічну тенденцію відзначали і в динаміці ТБК-активних продуктів пероксидного окиснення ліпідів - через 21 добу їх рівень перевищував контрольні показники у 2,7 раза $(p<0,05)$.

2. За своєю динамікою активація системи пероксидного окиснення ліпідів у групі піддос- лідних тварин із скелетною травмою, яким накладали кровоспинні джгути, та групі піддослідних тварин, в яких скелетна травма поєднувалась із закритою травмою органів черевної порожнини, була подібною. Таким чином, ішемію-реперфузію нижніх кінцівок можна розглядати як компонент поєднаної травми.

Перспективи подальших досліджень. У перспективі передбачається розробити патогенетично обґрунтовані засоби корекції системних змін, що виникають під впливом реперфузії кінцівки.

\section{СПИСОК ЛІТЕРАТУРИ}

1. Trends in 1029 trauma deaths at a level 1 trauma center / B. T. Oyeniyi, E. E. Fox, M. Scerbo [et al.] // Injury. - 2017. - 48 (1). - P. 5-12.

2. Multiple trauma and emergency room management / M. Frink, P. Lechler, F. Debus, S. Ruchholtz // Dtsch. Arztebl. Int. - 2017. - 114 (29-30). - P. 497-503. doi: 10.3238/arztebl.2017.0497.

3. Kashani P. Management of multiple traumas in emergency medicine department: A review / P. Kashani, A. Saberinia // J. Family Med. Prim. Care. - 2019. 8 (12). - P. 3789-3797.

4. Ratnasekera A. Damage control resuscitation in surgical critical care / A. Ratnasekera, P. Reilly, P. Ferrada // Damage Control in Trauma Care; J. Duchesne, K. Inaba, M. Khan eds. Chapter 15. - Springer, AG, 2018. - P. 287.

5. Maegele M. The acute coagulopathy of trauma: mechanisms and tools for risk stratification / M. Maegele, P. Spinella, H. Schöchl // Shock. - 2012. - No. 38. P. 450-458.

6. Цимбалюк Г. Ю. Стан добового діурезу нирок в умовах ішемічно-реперфузійного синдрому кінцівок, травми органів черевної порожнини, ускладненої гіповолемічним шоком, та їх поєднання у ранньому періоді травматичної хвороби / Г. Ю. Цимбалюк //

\section{REFERENCES}

1. Oyeniyi, B.T., Fox, E.E., Scerbo, M., Tomasek, J.S., Wade, C.E., \& Holcomb J.B. (2017). Trends in 1029 trauma deaths at a level 1 trauma center. Injury, 48 (1), 5-12.

2. Frink, M., Lechler, P., Debus, F., \& Ruchholtz, S. (2017). Multiple trauma and emergency room management. Dtsch. Arztebl. Int., 114 (29-30), 497-503. doi: 10.3238/arztebl.2017.0497.

3. Kashani, P., \& Saberinia, A. (2019). Management of multiple traumas in emergency medicine department: A review. J. Family Med. Prim. Care, 8 (12), 3789-3797.
Здобутки клініч. і експерим. медицини. - 2018. № 3 (35). - C. 163-169.

7. Chronology of mitochondrial and cellular events during skeletal muscle ischemia-reperfusion / S. Paradis, A. L. Charles, A. Meyer [et al.] // American Journal of Physiology. Cell Physiology. - 2016. - 310 (11). P. C968-C982. doi: 10.1152/ajpcell.00356.2015.

8. КозакД. В. Особливості показників пероксидного окиснення ліпідів в динаміці раннього і пізнього періодів політравми / Д. В. Козак //Актуальні проблеми транспортної медицини. - 2012. - № 3. - С. 103-106.

9. Петухова О. В. Содержание липопротеидов и продуктов перекисного окисления липидов у больных в остром периоде политравмы / О. В. Петухова, И. М. Устьянцева, В. В. Агаджанян // Политравма. 2006. - № 3. - C. 65-68.

10. Volotovska N. V. Changes in the glutathione systems activity of internal organs in the first hours of experimental limb ischemia-reperfusion syndrome, combined with blood loss and mechanical injury / N. V. Volotovska, T. C. Nhokwara, I. V. Zhulkevych // Здобутки клініч. і експерим. медицини. - 2019. - № 1 (37). С. 23-27.

11. Доклінічні дослідження лікарських засобів : метод. рек. / за ред. О. В. Стефранова. - К. : Авіцена, 2001. - 528 c.

4. Ratnasekera, A., Reilly, P. \& Ferrada, P. (2018). Damage control resuscitation in surgical critical care. Damage Control in Trauma Care. Duchesne J., Inaba K., Khan M. (Eds.). Chapter 15. Springer, AG.

5. Maegele M., Spinella, P., \& Schöchl, H. (2012). The acute coagulopathy of trauma: mechanisms and tools for risk stratification. Shock, 38, 450-458.

6. Tsymbaliuk, H.Yu. (2018). Stan dobovoho diurezu nyrok v umovakh ishemichno-reperfuziinoho syndromu kintsivok, travmy orhaniv cherevnoi porozhnyny, uskladnenoi hipovolemichnym shokom, ta yikh poiednannia u 
rannomu periodi travmatychnoi khvoroby [Daily urine renal state under ischemic-reperfusion syndrome of limbs, abdominal injury with hypovolemic shock and their combination in the early period of traumatic disease]. Zdobutky klinichnoi i eksperymentalnoi medytsyny Achievements of Clinical and Experimental Medicine, 3 (35), 163-169 [in Ukrainian].

7. Paradis, S., Charles, A.L., Meyer, A., Lejay, A., Scholey, J.W., Chakfé, N., ..., Geny, B. (2016). Chronology of mitochondrial and cellular events during skeletal muscle ischemia-reperfusion. American Journal of Physiology Cell Physiology, 310 (11), C968-C982. DOI: 10.1152/ajpcell.00356.2015.

8. Kozak, D.V. (2012). Osoblyvosti pokaznykiv peroksydnoho okysnennia lipidiv $v$ dynamitsi rannoho i piznoho periodiv politravmy [Features of indicators of lipid peroxidation in the dynamics of early and late periods of polytrauma]. Aktualni problemy transportnoi medytsyny -
Actual Problems of Transport Medicine, 3, 103-106 [in Ukrainian].

9. Petukhova, O.V., Ustyantseva, I.M., \& Agadzhanyan, V.V. (2006). Soderzhaniye lipoproteidov i produktov perekisnogo okisleniya lipidov $u$ bolnykh $v$ ostrom periode politravmy [Content of lipoproteins and lipid peroxidation products in patients in the acute period of polytrauma]. Politravma - Polytrauma, 3, 65-68 [in Russian].

10. Volotovska, N.V., Nhokwara, T.C., \& Zhulkevych, I.V. (2019). Changes in the glutathione systems activity of internal organs in the first hours of experimental limb ischemia-reperfusion syndrome, combined with blood loss and mechanical injury. Zdobutky klinichnoi i eksperymentalnoi medytsyny-Achievements of Clinical and Experimental Medicine, 1, 23-27.

11. Stefanov, O.V. (2001). Doklinichni doslidzhennia likarskykh zasobiv: metod. rekomend. [Preclinical drug research: A guidelines]. Kyiv: Avitsenna [in Ukrainian].

\author{
С. В. Гариян \\ УКРАИНСКИЙ НАУЧНО-ПРАКТИЧЕСКИЙ ЦЕНТР ЭКСТРЕННОЙ МЕДИЦИНСКОЙ ПОМОЩИ \\ И МЕДИЦИНЫ КАТАСТРОФ МОЗ УКРАИНЫ, КИЕВ
}

\title{
ИЗМЕНЕНИЯ В СИСТЕМЕ ПЕРЕКИСНОГО ОКИСЛЕНИЯ ЛИПИДОВ У ПОДОПЫТНЫХ ЖИВОТНЫХ ВСЛЕДСТВИЕ МОДЕЛИРУЕМОЙ СОЧЕТАННОЙ АБДОМИНО-СКЕЛЕТНОЙ ТРАВМЫ И ИШЕМИИ-РЕПЕРФУЗИИ НИЖНИХ КОНЕЧНОСТЕЙ
}

\section{Резюме}

Вступление. В статье приведены результаты экспериментального исследования, во время которого изучали влияние реперфузии нижних конечностей, после наложения кровоостанавливающих жгутов, на изменения показателей системы перекисного окисления липидов в сыворотке крови в условиях абдоминоскелетной травмы и массивной наружной кровопотери. Они показали, что реперфузия нижних конечностей в сочетании с моделируемыми травмами вызывает значительную активацию этой системы в течение 21-го дня посттравматического периода.

Цель исследования - изучить влияние реперфузии конечности на модели сочетанной абдоминоскелетной травмы на изменения показателей системы перекисного окисления липидов.

Методы исследования. Эксперимент проведен на 130-ти нелинейных крысах-самцах массой 190220 г. В исследовательских группах была смоделирована реперфузия нижних конечностей в сочетании с абдомино-скелетной травмой и проанализирована динамика изменений показателей ТБК-активных продуктов и диеновых конъюгатов к 21 суткам посттравматического периода. Достоверность различий между контрольной и исследовательскими группами оценивали с использованием непараметрического критерия Манна - Уитни.

Результаты и обсуждение. Результаты анализа динамики изменений показателей диеновых конъюгатов и ТБК-активных продуктов перекисного окисления липидов в исследовательских группах свидетельствуют о том, что наложение кровоостанавливающих жгутов на обе нижние конечности подопытных животных вызвало значительную активацию этой системы в посттравматический период. По своей динамике активация этой системы в группе подопытных животных со скелетной травмой, которым накладывали кровоостанавливающие жгуты, и группе подопытных животных, у которых скелетная травма сочеталась с закрытой травмой органов брюшной полости, была похожей. Таким образом, ишемию-реперфузию нижних конечностей можно рассматривать как компонент сочетанной травмы.

Вывод. Наложение кровоостанавливающих жгутов на две нижние конечности на 2 ч вызывает длительную активацию системы липидной пероксидации, что подтверждается статистически 
достоверным $(p<0,05)$ увеличением содержания диеновых конъюгатов и ТБК-активных продуктов перекисного окисления липидов с максимумом через 21 сутки в посттравматический период.

КЛЮЧЕВЫЕ СЛОВА: ишемия-реперфузия; жгут; эксперимент; сочетанная травма; диеновые конъюгаты; ТБК-активные продукты; кровотечение.

S. V. Garian

UKRAINIAN SCIENTIFIC AND PRACTICAL CENTER OF EMERGENCY AND DISASTER MEDICINE, MINISTRY OF HEALTH OF UKRAINE, KYIV

\title{
CHANGES IN THE LIPID PEROXIDATION SYSTEM IN EXPERIMENTAL ANIMALS AFTER COMBINED ABDOMINO-SKELETAL TRAUMA AND ISCHEMIA REPERFUSION OF THE LOWER EXTREMITIES
}

\begin{abstract}
Summary
Introduction. The article presents the results of an experimental study that examined the effect of lower extremity reperfusion, after the applying of hemostatic plaits, on changes in serum lipid peroxidation in case of combined abdominal and skeletal trauma and massive external blood loss. The results of the study showed that reperfusion of the lower extremities in combination with the simulated traumas caused a significant activation of the LPO system within 21 days after trauma.

The aim of the study - to learn the effect of limb reperfusion in a model of combined abdominal-skeletal injury on changes in lipid peroxidation system.

Research Methods. An experiment was conducted on 130 non-linear male rats weighing 190-220 grams. In the study groups, reperfusion of the lower extremities in combination with abdominal-skeletal trauma was simulated and the dynamics of changes in TBA-active products, diene conjugates up to 21 days after the traumatic period were analyzed. The likelihood of differences between the control group and the study group was evaluated using the non-parametric Mann - Whitney test.
\end{abstract}

Results and Discussion. After analyzing the dynamics of changes in diene conjugates and TBA-active LPO products in the study groups, we obtained results showing that the imposition of hemostatic tourniquet on both lower extremities of the experimental animals caused significant activation of the LPO system in the post-traumatic period. According to their dynamics, the activation of the LPO system in the group of experimental animals with skeletal trauma and the imposition of hemostatic harnesses and the group of experimental animals where the skeletal trauma was combined with closed trauma of the abdominal organs were similar. Thus, ischemia-reperfusion of the lower extremities can be considered as a component of combined trauma.

Conclusion. The imposition of hemostatic tourniquet on the two lower extremities, within two hours, causes a prolonged activation of the lipid peroxidation system, which is confirmed by statistically significant $(p<0.05)$ increase in the content of diene conjugates and TBA-active products, with a maximum after 21 days.

KEY WORDS: ischemia; reperfusion; tourniquet; experiment; combined trauma; diene conjugates;
bleeding. 